\title{
Analisis Pengendalian Persediaan Menggunakan Metode Probabilistik dengan Kebijakan Backorder dan Lost sales
}

\author{
Dian Serena Pulungan, Erika Fatma* \\ Manajemen Logistik Industri Elektronika, Politeknik APP Jakarta, Indonesia \\ *Korespondensi penulis, surel: rika-fatma@kemenperin.go.id
}

\begin{abstract}
High fluctuating demand at companies encourages to perform inventory control. This study aims to determine the exact inventory control method for the company, which minimizes the inventory cost and inventory amount provided by the company. This research analyzes various aspects related to the system and inventory cost used by the company. This research uses probabilistic inventory methods, which are probabilistic controls, $P$ models, and $Q$ models. Based on data processing, $P$ model provides an optimal solution. $P$ system provides cost and amount of optimal safety stock compared to other inventory models.
\end{abstract}

Keywords: Inventory system, Safety stock, Probabilistic, P system, Q system.

\begin{abstract}
Abstrak
Permintaan produk yang fluktuatif, memaksa perusahan untuk dapat melakukan pengendalian persediaan. Penelitian ini bertujuan untuk menentukan metode pengendalian persediaan yang tepat bagi perusahan, sehingga total biaya persediaan dan jumlah persediaan yang disediakan perusahan dapat di minimasi, Penelitian ini, menganalisis berbagai aspek terkait sistem dan biaya persediaan yang digunakan perusahan. Penelitian ini menggunakan metode persediaan probabilistik. Meliputi pengendalian probabilistik sederhana, model $P$, dan model $Q$. berdasarkan pengolahan data, model $P$ memberikan solusi optimal. Model $P$ memberikan biaya dan jumlah persediaan pengaman (safety stock) optimal dibandingkan model persediaan lainnya.
\end{abstract}

Kata kunci: Sistem persediaan probabilistik, model $P$, model $Q$, safety stock

\section{Pendahuluan}

Kenaikan dan penurunan permintaan umumnya dipengaruhi faktor musiman barang. Untuk mengatasi ketidakstabilan permintaan, pada umumnya perusahan menyediakan safety stock dalam tingkat tertentu. Perusahan perlu memantau tingkat persediaan yang dimiliki sebagai upaya mengendalikan aset perusahan. Pemantauan persediaan dilakukan melalui pencatatan stok persediaan yang ada di gudang (saat penerimaan barang, penyimpanan di gudang, dan pengeluaran barang dari gudang) yang prosesnya diatur berdasarkan prosedur yang dibuat oleh perusahan [1].

Perusahan yang diteliti merupakan distributor perlengkapan alat tulis kantor. Produk yang di distribusikan perusahan sangat beragam, mulai dari peralatan tulis sampai perangkat elektronik yang umumnya digunakan untuk kegiatan perkantoran. Perusahan membeli produk dari supplier, kemudian mendistribusikannya kepada salah satu jaringan toko buku dan perlengkapan kantor yang tersebar di berbagai wilayah di Indonesia. Pengiriman atau penjualan yang dilakukan perusahan didasarkan permintaan dari toko, di mana jumlah permintaan untuk setiap jenis produk sangat berfluktuasi setiap periodenya.

Saat ini, pengendalian persediaan didasarkan pada pengalaman periode sebelumnya. Untuk mengantisipasi tingginya fluktuasi permintaan produk, perusahan 
menyediakan persediaan pengaman (safety stock) untuk tiap produk sebanyak $30 \%$ dari selisih antara nilai rata-rata barang masuk (pembelian) dan barang keluar (penjualan) pada periode tertentu. Perhitungan persediaan cadangan didasarkan data permintaan tahun sebelumnya dan metode pengendalian ini berlaku untuk seluruh jenis produk. Hal lain yang belum diperhatikan perusahaan adalah penentuan waktu pemesanan kembali. Penentuan titik pemesanan kembali, dilakukan dengan memperkirakan waktu pesan dengan waktu kedatangan barang (lead time). Namun, belum mempertimbangkan potensi kenaikan permintaan yang memungkinkan terjadinya kehabisan barang (stock out) yang harus dihindari.

Berdasarkan permasalahan tersebut, diketahui terdapat potensi perbaikan sistem pengendalian persediaan produk perusahaan. Salah satu produk dipilih pada studi kasus ini karena memiliki karakteristik siklus hidup produk yang pendek, namun, disisi lain memiliki harga yang cukup tinggi. Sehingga kesalahan dalam perencanaan pengendalian persediaan sangat diperlukan, untuk menghindari risiko kerugiaan yang tinggi. Manajemen persediaan merupakan rangkaian kegiatan terkait perencanaan, pelaksanaan, dan pengawasan penentuan kebutuhan material sehingga kebutuhan operasi dapat dipenuhi pada waktunya dan persediaan tersedia secara optimal [2]. Tingkat persediaan barang menyebabkan biaya persediaan yang tinggi, dan kesalahan perhitungan akan berakibat penumpukan barang di gudang sehingga menimbulkan kerusakan atau barang tidak tersedia pada waktu dibutuhkan.

Terdapat dua pendekatan pengendalian persediaan optimum, yaitu pengendalian persediaan deterministik dan probabilistik[3]. Model deterministik adalah model yang menganggap semua parameter persediaan diketahui secara pasti. Model deterministik yang banyak digunakan adalah EOQ (Economic Order Quantity) dan Program Dinamis $[4,5]$. EOQ bertujuan untuk menentukan ukuran pemesanan paling ekonomis yang dapat meminimalkan biaya persediaan [6-11]. Model probabilistik digunakan apabila salah satu dari permintaan, lead time atau keduanya belum diketahui secara pasti [12]. Perbedaan utama model deterministik dan probabilistik adalah keberadaan safety stock atau persediaan pengaman yang dimunculkan untuk mengatasi ketidakpastian permintaan maupun lead time [13]. Metode probabilistik dapat dikelompokan menjadi model P dan Q. Persediaan model Q ditandai dengan besarnya pemesanan tetap untuk setiap pesanan. Sedangkan metode $\mathrm{P}$ ditandai dengan periode pemesanan yang selalu tetap dalam sistem persediaan terdapat dua kebijakan jika persediaan yang dimiliki tidak dapat memenuhi permintaan pelanggan yaitu backorder atau Lost sales [14].

Berbagai penelitian telah dilakukan untuk menentukan persediaan optimum di perusahaan manufaktur. Namun, penelitian tersebut belum memberikan gambaran mengenai kebijakan Backorder dan Lost sales pada model persediaan probabilistik P dan Q terhadap biaya total persediaan. Penelitian ini memberikan sumbangsih ilmu pengetahuan dalam perbandingan berbagai kebijakan persediaan terutama Backorder dan Lost sales pada model persediaan probabilistik P dan Q. Tujuan penelitian adalah membuat kebijakan persediaan pada model persediaan probabilistik $\mathrm{P}$ dan $\mathrm{Q}$ dengan mempertimbangkan Backorder dan Lost sales. Model persediaan probabilistik P dan Q kemudian dibandingkan dengan biaya persediaan aktual sesuai kebijakan manajemen perusahaan dengan metode persediaan yang umum digunakan pada pengendalian persediaan probabilistik. Sehingga dapat diketahui metode pengendalian yang paling sesuai dan untuk mengetahui tingkat persediaan optimum yang dapat meminimalkan biaya persediaan perusahaan dengan memerhatikan pemenuhan pelayanan kepuasan pelanggan. 


\section{Metode Penelitian}

Pengolahan data dilakukan dengan membandingkan biaya total persediaan yang dilakukan perusahaan berdasarkan penentuan safety stock yang ditentukan perusahaan dengan metode probabilistik lainnya. Biaya total persediaan dihitung menggunakan metode: Probabilistik sederhana, Probabilistik P (backorder dan Lost sales) dan Model Probabilistik Q (Back order and Lost sales). Perhitungan total biaya persediaan dari seluruh model tersebut dibandingkan untuk mengetahui pengendalian persediaan yang tepat dan dapat meminimasi biaya persediaan perusahaan, dengan memerhatikan tingkat pelayanan kepada pelanggan.

\section{Model Persediaan Probabilistik}

Metode pengendalian persediaan probabilistik adalah model persediaan dengan karakteristik permintaan dan kedatangan pesanan yang tidak diketahui secara pasti sebelumnya, tetapi nilai ekspektasi, variansi dan pola distribusi kemungkinannya dapat diprediksi dan didekati berdasarkan distribusi probabilitas [15]. Terdapat tiga metode pengendalian persediaan probabilistik, yaitu Probabilistik sederhana; Metode P, yang memiliki aturan bahwa tiap pemesanan bersifat regular pada rentang periode yang tetap dan kuantitas pemesanan berbeda-beda; Metode Q, memiliki ukuran (kuantitas) pemesanan tetap untuk tiap pesanan, dan waktu pemesanannya bervariasi [16]. Kriteria yang digunakan dalam menentukan metode pengendalian persediaan terbaik adalah minimasi biaya inventori total selama horizon perencanaan. Berbagai biaya yang dipertimbangkan dalam pengelolaan persediaan di antaranya [14]:

1. Ongkos pembelian (Ob), yaitu harga beli/produksi per unit. Ob merupakan perkalian antara jumlah barang yang dibeli (D) dengan harga barang per unitnya (p)

2. Ongkos pemesanan (Op), yaitu biaya yang dikeluarkan untuk pemesanan tiap kali pesan. Ongkos pesan merupakan perkalian antara frekuensi pemesanan (f) dan ongkos setiap kali pemesanan barang (A).

3. Ongkos Simpan (Os), yaitu biaya yang ditimbulkan akibat penyimpanan produk pada periode tertentu. Ongkos simpan merupakan hasil perkalian antara jumlah inventori rata-rata yang ada di gudang $(\mathrm{m})$ dengan ongkos simpan per unit per periode (h).

4. Ongkos kekurangan persediaan $\left(\mathrm{O}_{\mathrm{k}}\right)$, yaitu konsekuensi tidak terpenuhinya pesanan, dapat berbentuk kekurangan dapat dipesan-ulang (backorder) atau batal (Lost sales).

Persamaan ongkos inventori total $\left(\mathrm{O}_{\mathrm{T}}\right)$ dapat dilihat pada persamaan 1:

$$
\mathrm{O}_{\mathrm{T}}=\mathrm{O}_{\mathrm{b}}+\mathrm{O}_{\mathrm{p}}+\mathrm{O}_{\mathrm{s}}+\mathrm{O}_{\mathrm{k}}
$$

Dalam pengolahan digunakan beberapa asumsi untuk menyederhanakan masalah. Asumsi yang digunakan dalam penelitian ini adalah:

a. Permintaan bersifat probabilistik dan berdistribusi normal .

b. Waktu antar pesanan konstan untuk setiap pemesanan, barang datang serentak.

c. Harga barang konstan terhadap kuantitas/waktu

d. Ongkos pesan (A) konstan untuk setiap pemesanan dan ongkos simpan (h) sebanding dengan harga barang dan waktu penyimpanan

e. Ongkos kekurangan persediaan sebanding dengan jumlah barang yang tidak dapat dilayani, atau sebanding dengan waktu (tidak tergantung dengan jumlah kekurangan). 


\section{Sistem Inventori Probabilistik Sederhana}

Dalam perhitungan probabilistik, terlebih dahulu harus dicari nilai dari ekspektasi kekurangan permintaan yang tidak terpenuhi $(\mathrm{N})$ pada persamaan 2 , karena metode ini digunakan tingkat permintaan yang berfluktuasi dan tidak dapat diprediksi. Nilai ini merupakan fungsi distribusi normal dari terjadinya kekurangan barang selama lead time [17]

$$
\mathrm{N}=\mathrm{S}_{\mathrm{L}}\left[\mathrm{f}\left(\mathrm{z}_{\mathrm{\alpha}}\right)-\Psi\left(\mathrm{z}_{\mathrm{\alpha}}\right)\right]
$$

Setelah mencari nilai N, selanjutnya dapat dihitung kebijakan inventori untuk menentukan ongkos total yang paling optimal. Persamaan dalam kebijakan inventori meliputi ukuran lot pemesanan (qo) pada persamaan 3, cadangan pengaman (ss) pada persamaan 4, saat pemesanan ulang (r) pada persamaan 5 .

(i) Ukuran lot pemesanan ekonomis (qo)

$$
q o=\sqrt{\frac{2 D(A+C u N)}{h}}
$$

(ii) Cadangan pengaman (ss)

$$
\mathrm{SS}=\mathrm{Z}_{\alpha} \mathrm{S} \sqrt{ } \mathrm{L}
$$

(iii) Saat pemesanan ulang $(r)$

$$
r=\mathrm{DL}+\mathrm{ss}
$$

Setelah diketahui kebijakan inventori, dapat dihitung tingkat pelayanan $(\eta)$ seperti pada persamaan 6 .

$$
\eta=1-\frac{N}{D L}
$$

Output dari perhitungan persediaan dengan menggunakan metode apapun adalah untuk mencari ongkos total (OT) yang paling optimal, untuk mencari ongkos total paling optimal di metode probabilistik dapat dilihat pada persamaan 7 .

$$
O T=D p+\frac{A D}{q o}+h \frac{\mathrm{qo}+\mathrm{ss}}{2 !}+\frac{\mathrm{CuDN}}{q o}
$$

\section{Metode Probabilistik Model P}

Kebijakan persediaan dengan model $P$ berkaitan dengan penentuan besarnya stok operasional yang harus disediakan beserta dengan cadangan pengamannya. Model $\mathrm{P}$ memecahkan tiga permasalahan, yaitu: Jumlah barang untuk setiap kali pemesanan (Q): Waktu pemesanan dilakukan (T) dan besarnya cadangan pengaman (Ss) [17]. Model $P$ diawali dengan menentukan periode antar pemesanan ( $T$ ) yang diasumsikan konstan. Kemudian menentukan besarnya ukuran pemesanan ekonomis (qo) untuk setiap periode $T$ yang besarnya dapat berbeda antara tiap pemesanan. Selanjutnya, menentukan nilai cadangan pengaman (ss) yang harus disediakan untuk meredam permintaan dengan fluktuasi yang tidak teratur, dengan menyeimbangkan optimasi biaya dan pelayanan pelanggan. Model $\mathrm{P}$ dapat dilakukan dengan asumsi Lost sales atau back order. 


\section{Model $P$ dengan Back Order}

Model ini hanya berlaku jika kekurangan persediaan diperlakukan dengan back order. Dalam hal ini, pengguna menunggu barang yang diminta sampai tersedia.

1) Hitung nilai To pada persamaan 8.

$$
T o=\sqrt{\frac{2 A}{D h}}
$$

2) Hitung nilai $\alpha$ dan $R$ dengan menggunakan persamaan 9 dan 10.

$$
\begin{aligned}
& \alpha=\frac{T h}{C u} \\
& R=D(T o+L)+Z \alpha S \sqrt{T+L}
\end{aligned}
$$

3) Hitung total onkos inventori dengan menggunakan persamaan 11.

$$
O T=D p+\frac{A}{T}+h\left(R-D L+\frac{D T}{2}\right)+\left(\frac{C u}{T} x N\right)
$$

4) Ulangi langkah 2 dengan mengubah $\mathrm{To}_{\mathrm{o}}=\mathrm{To}_{\mathrm{O}}+\Delta \mathrm{To}$

i. Jika hasil $\left(O_{T}\right)_{0}$ baru lebih besar dari $\left(O_{T}\right)_{0}$ awal, iterasi penambahan To dihentikan. Kemudian dicoba dengan iterasi pengurangan $\left(T_{o}=T o-\Delta T o\right)$ sampai ditemukan nilai $T=$ To yang memberikan nilai ongkos total minimal.

ii. Jika hasil $\left(\mathrm{O}_{\mathrm{T}}\right)_{0}$ baru lebih kecil dari $\left(\mathrm{O}_{\mathrm{T}}\right)_{0}$ awal, iterasi penambahan $(T o=T o+\Delta T o)$ dilanjutkan dan baru berhenti apabila $\left(\mathrm{O}_{\mathrm{T}}\right)_{0}$ b baru lebih besar dari $\left(O_{T}\right)_{\circ}$ yang dihitung sebelumnya. Harga $T_{0}$ yang memberikan ongkos total terkecil $\left(O_{T}\right)$ merupakan selang waktu optimal.

\section{Model $P$ dengan Lost sales}

Model berikut ini hanya berlaku jika kekurangan persediaan diperlakukan sebagai Lost sales. Dalam hal ini, konsumen tidak menunggu sampai barang tersedia. Pemakai akan pergi dan mencari barang kebutuhannya di tempat lain. Rumus dan ketentuan iterasi dalam perhitungan back order dan lost sales hampir sama, perbedaanya terletak pada perhitungan a. Rumus a dalam metode lost sales menggunakan persamaan 12 .

$$
\alpha=\frac{T h}{T h+C u}
$$

\section{Metode Probabilistik Model Q}

Model probabilistic Q berkaitan dengan penentuan besarnya persediaan operasi dan persediaan pengaman. Model Q ini merupakan pengembangan model probabilistic sederhana, namun tidak menetapkan terlebih dahulu tingkat pelayanannya. Dalam Model $\mathrm{P}$ tingkat pelayanannya ditentukan bersamaan dengan optimasi ongkos. Reaksi konsumen terhadap kondisi kekurangan bahan yang terjadi di perusahaan dapat dibagi menjadi dua, yaitu backorder dan lost sale [17].

\section{Model Q dengan Back Order}

Terdapat beberapa teknik yang dapat digunakan dalam menyelesaikan kasus back order menggunakan model Q. Salah satu langkah yang dapat digunakan adalah langkah 
penyelesaian yang di kemukakan oleh Hadley-Within [18]. Langkah penyelesaian dilakukan dengan menentukan nilai qo dan $r$, yang diperoleh dengan langkah berikut.

1) Hitung nilai qo 1 awal sama dengan nilai qo dengan persamaan 13.

$$
q o 1=\sqrt{2 A D / h}
$$

2) Berdasarkan nilai $q 0_{1}$ yang diperoleh akan dapat dicari besarnya kemungkinan kekurangan inventori a dapat dicari menggunakan persamaan 14. Dan perhitungan $\mathrm{r}_{1}$ dapat dicari menggunakan persamaan 15.

$$
\begin{aligned}
& \alpha=\frac{h q o}{C u D} \\
& \mathrm{r}_{1}=D L+z a S \sqrt{ } L
\end{aligned}
$$

3) Dengan demikian $r_{1}$ yang diperoleh akan dapat dihitung nilai qo2 berdasarkan formula yang diperoleh dari persamaan 16 .

$$
q o 2=\sqrt{2 D}[A+C u N] / h
$$

4) Hitung kembali besarnya nilai $\alpha=h_{02} / \mathrm{CuD}$ dan nilai $r_{2}$ dengan menggunakan persamaan 17.

$$
r_{2}=D L+z a S \sqrt{ } L
$$

5) Bandingkan nilai $r_{1}$ dan $r_{2}$; jika harga $r_{2}$ relatif sama dengan $r_{1}$ iterasi selesai dan akan diperoleh $r=r_{2}$ dan $q o=q o_{2}$. Jika tidak kembali ke langkah $\mathrm{c}$ dengan menggantikan nilai $r_{1}=r_{2}$ dan $q o_{1}=q o_{2}$.

6) Ekspektasi ongkos total per tahun dapat dihitung dengan persamaan 18.

$$
\mathrm{OT}=D p+\frac{A D}{q o}+h\left(\frac{q o+r-D L}{2}\right)+C u\left(\frac{D}{q o}\right) x N
$$

\section{Model Q dengan Lost Sales}

Model berikut berlaku jika kekurangan inventori diperlakukan dengan lost sales. Konsumen tidak menunggu barang yang diminta sampai dengan tersedia. Pencarian solusi $\mathrm{q}^{*}$ dan $\mathrm{r}^{*}$ metode Hadley-Within [14]. Rumus dan ketentuan iterasi dalam perhitungan back order dan lost sales hampir sama, perbedaanya terletak pada perhitungan a. Rumus a dalam metode lost sales dapat dilihat pada persamaan 19.

$$
\alpha=\frac{h q o}{C u D+h q o}
$$

\section{Hasil dan Pembahasan}

Jumlah permintaan yang tidak pasti membuat pendekatan probabilistik sebagai metode yang tepat untuk menganalisis sistem pengendalian persediaan perusahaan. Tabel 1 menunjukkan data permintaan selama 12 periode. Selisih permintaan menjadi dasar bagi perusahaan untuk menentukan nilai safety stock. Berdasarkan kebijakan, safety stock ditentukan sebesar 30\% dari selisih barang keluar-masuk. Nilai ini menjadi dasar untuk membandingkan biaya persediaan berdasarkan metode yang ditetapkan perusahaan dengan metode lain yang dapat menekan biaya. 


\section{Metode Probabilistik Sederhana}

Tabel 2 menjelaskan komponen yang dibutuhkan dalam perhitungan persediaan dengan metode probabilistik sederhana. Nilai D, S, P, L, A, h dan Cu diperoleh dari hasil observasi, wawancara dengan perusahaan. Berdasarkan data tersebut, nilai $\sqrt{\mathrm{L}}, \mathrm{S} \sqrt{\mathrm{L}}$, dan SL dapat diketahui. Selanjutnya persentase kekurangan barang (a) dihitung atas dasar ekspektasi perusahan, yang diperoleh dari selisih antara barang masuk dan barang keluar (Tabel 1). Kemudian, nilai $\mathrm{z}_{\alpha}, \mathrm{f}\left(\mathrm{z}_{\alpha}\right), \Psi\left(\mathrm{z}_{\alpha}\right)$ ditentukan berdasarkan nilai $\alpha$ pada tabel distribusi normal. Setelah semua komponen perhitungan diketahui, langkah selanjutnya menghitung ukuran lot pemesanan ekonomis (qo) tingkat safety stock (ss), reorder point $(r)$, serta tingkat pelayanan $(\eta)$, berdasarkan persamaan (2), (3), (4), (5), dan (6). Langkah terakhir adalah menghitung ongkos total persediaan (OT) menggunakan persamaan (7).

Tabel 1 Perhitungan Ongkos Kekurangan

\begin{tabular}{cccccc}
\hline Periode & $\begin{array}{c}\text { Barang } \\
\text { Keluar }\end{array}$ & $\begin{array}{c}\text { Barang } \\
\text { Masuk }\end{array}$ & Selisih & Harga Produk & $\begin{array}{c}\text { Ongkos } \\
\text { Kekurangan }\end{array}$ \\
1 & 217 & 205 & 12 & & \\
2 & 232 & 215 & 17 & & \\
3 & 273 & 211 & 62 & & \\
4 & 267 & 218 & 49 & Rp. 3.400 .000 & Rp. 103.030 \\
5 & 249 & 214 & 35 & & \\
6 & 242 & 222 & 20 & & \\
7 & 254 & 225 & 29 & & \\
8 & 263 & 227 & 36 & & \\
Total & 1997 & 1737 & 260 & & \\
\hline
\end{tabular}

Tabel 2 Komponen Pendukung Perhitungan Persediaan dengan Metode Probabilistik Sederhana

\begin{tabular}{lcc}
\hline \multicolumn{3}{c}{ Komponen perhitungan persediaan } \\
\hline Rata-rata permintaan (D) & 250 & unit \\
Standar deviasi permintaan (S) & 19 & unit \\
Harga produk (P) & 3.400 .000 & Rp. \\
Waktu tunggu/lead time (L) & 0.0833 & periode \\
Biaya pesan (A) & 2.146 .364 & $\mathrm{Rp.}$ \\
Biaya simpan (h) & 20.373 & $\mathrm{Rp.}$ \\
Biaya kekurangan (Cu) & 103.000 & $\mathrm{Rp}$. \\
Standar deviasi dari lead time $(\mathrm{z} \alpha)$ & 1.15 & \\
$\mathrm{f}(\mathrm{z} \alpha)$ & 0.2059 & \\
$\Psi(\mathrm{z} \alpha)$ & 0.0621 & \\
\hline
\end{tabular}

Berdasarkan hasil perhitungan pada Tabel 3, terlihat terdapat perbedaan antara perhitungan berdasarkan kebijakan perusahaan dengan perhitungan usulan. Perbedaan terdapat pada tingkat safety stock dan reorder point, yang berdampak pada ongkos total persediaan. Perusahan menetapkan tingkat safety stock pada tingkat yang cukup tinggi, yaitu 78 unit. Berdasarkan perhitungan model persediaan sederhana (persamaan 2,3, dan 4), diketahui bahwa tingkat safety stock optimal berada pada tingkat 6 unit. 
Perbedaan ini sangat signifikan, mengingat tingkat safety stock yang tinggi dapat meningkatkan biaya persediaan. Dengan tingkat safety stock berdasarkan perhitungan penulis, 6 unit sudah mencukupi untuk mengantisipasi permintaan, dan dapat menekan biaya persediaan.

Tabel 3 Rincian Hasil Perbandingan Kebijakan Persediaan Metode Probabilistik Sederhana

\begin{tabular}{cccccc}
\hline Kebijakan & Qo & ss & r & $\eta$ & OT \\
\hline Perusahaan & 236 & 78 & 99 & $95 \%$ & Rp. 855.077.735 \\
Usulan & 236 & 6 & 27 & $95 \%$ & Rp. 853.624.314* \\
\hline
\end{tabular}

Pada Tabel 3, terlihat bahwa reorder point yang ditetapkan perusahaan sebesar 99 unit. Namun, berdasarkan perhitungan usulan nilai reorder point (persamaan 5), cukup berada pada titik 27 unit. Tingkat reorder point yang tinggi, dapat meningkatkan total biaya persediaan. Penurunan nilai safety stock dan reorder point yang diajukan tetap memenuhi tingkat pelayanan pelanggan yang ditetapkan oleh perusahaan sebesar 95\%. Pada Tabel 4, terlihat bahwa biaya persediaan ditekan lebih optimal. Berdasarkan kebijakan perusahaan, total biaya persediaan mencapai $\mathrm{Rp}$ 855.077.735. Berdasarkan metode yang digunakan, biaya total persediaan dapat ditekan menjadi Rp 853.624.314. Artinya, ongkos total persediaan dapat ditekan sebesar $\mathrm{Rp}$ 1.453.421.

\section{Metode P}

Model P terbagi menjadi 2 (dua), yaitu: metode back order dan Lost sales. Metode back order digunakan apabila terjadi kekurangan barang akibat permintaan lebih besar dibandingkan persediaan, perusahaan akan menggantikan kekurangan barang dilain waktu. Dalam kasus Lost sales, apabila terjadi kekurangan barang akibat permintaan, perusahaan tidak mengganti kekurangan dan permintaan dianggap sebagai permintaan yang hilang. Dalam model $\mathrm{P}$, terdapat iterasi untuk menentukan persediaan optimal. Iterasi dilakukan dalam dua tahap, yaitu mencoba menambahkan dan mengurangi jarak pesan. Iterasi dihentikan jika ongkos total yang dihitung lebih besar dari ongkos total sebelumnya.

Perhitungan model $\mathrm{P}$ backorder dilakukan dengan melalui iterasi penambahan periode pemesanan hingga diperoleh biaya total minimum (persamaan 8, 9, 10, 11 dan 12). Periode pemesanan optimum terjadi ketika pesanan dilakukan tiap 0,87 periode per tahun atau setiap 45 minggu sekali. Dengan menggunakan periode pemesanan yang sama, total biaya persediaan berdasarkan kebijakan perusahaan nilainya lebih tinggi dibandingkan model P usulan (Tabel 4). Model P Lost sales juga memberikan nilai yang lebih rendah pada perhitungan usulan (Tabel 5).

\section{Model Q}

Dalam pengendalian persediaan probabilistik model $\mathrm{Q}$, perhitungan dilakukan untuk menentukan ukuran pemesanan optimum ( $\mathrm{q}^{*}$ ). Pada Tabel 6, diketahui jumlah pemesanan optimum tiap kali pesan sebesar 236 unit dengan tingkat reorder point 26 unit jika menggunakan asumsi backorder dan reorder point 27 unit untuk asumsi lost sale. Perhitungan dilakukan dengan menggunakan persamaan 13, 14, 15, 16, 17, 18 dan 19 Hasil perhitungan memberikan total biaya persediaan lebih rendah dibandingkan kebijakan perusahaan. Hasil perhitungan ini memberikan tingkat pelayanan sebesar 
94\%, artinya dengan menggunakan metode ini perusahaan dapat memenuhi permintaan konsumen dengan probabilitas 94\%. Perbedaan biaya antara perhitungan usulan dengan model Q Lost sales dan back order tidak jauh berbeda.

Tabel 4 Rekapitulasi Perbandingan Kebijakan Inventory Model $P$-Backorder

\begin{tabular}{cccccc}
\hline Kebijakan & $\mathrm{T}$ & $\mathrm{R}$ & $\mathrm{ss}$ & $\eta$ & OT \\
\hline Perusahaan & 0,87 & 499 & 78 & $94 \%$ & Rp. 861.668.627 \\
Usulan & 0,87 & 256 & 18 & $94 \%$ & Rp. 856.742.285* \\
\hline
\end{tabular}

Tabel 5 Rekapitulasi Hasil Perbandingan Kebijakan Inventory Model P - Lost sales

\begin{tabular}{cccccc}
\hline Kebijakan & $\mathrm{T}$ & $\mathrm{R}$ & $\mathrm{ss}$ & $\eta$ & OT \\
\hline Perusahaan & 0,87 & 499 & 78 & $94 \%$ & Rp. 861.425.348 \\
Usulan & 0,87 & 256 & 18 & $94 \%$ & Rp. 856.499.009* \\
\hline
\end{tabular}

Tabel 6 Rekapitulasi Hasil Perbandingan Kebijakan Inventory Model Q Backorder

\begin{tabular}{cccccc}
\hline Kebijakan & Qo & R & ss & $\eta$ & OT \\
\hline Perusahaan & 236 & 99 & 78 & $95 \%$ & Rp. 855.081.77 \\
Usulan & 236 & 26 & 5 & $95 \%$ & Rp. 853.499.009 \\
\hline
\end{tabular}

Tabel 7 Rekapitulasi Hasil Perbandingan Kebijakan Inventory Model Q - Lost sales

\begin{tabular}{cccccc}
\hline Kebijakan & $\mathrm{T}$ & $\mathrm{R}$ & $\mathrm{ss}$ & $\eta$ & OT \\
\hline Perusahaan & 236 & 99 & 78 & $95 \%$ & Rp. 855.081.747 \\
Usulan & 236 & 27 & 6 & $95 \%$ & Rp. 853.622.091* \\
\hline
\end{tabular}

Tabel 8 Rekapitulasi Perbandingan Kebijakan Inventory

\begin{tabular}{cccc}
\hline \multicolumn{2}{c}{ Kebijakan Perusahaan } & \multicolumn{2}{c}{ Perhitungan Usulan } \\
\hline Sederhana & Rp. 855.077.735 & Sederhana & Rp. 853.624.314 \\
Model P, Lost sales & Rp.861.425.348 & Model P, Lost sales & Rp. 856.499.009 \\
Model P, Back order & Rp. 861.668.624 & Model P, Back order & Rp. 856.742.285 \\
Model Q, Lost sales & Rp. 855.081.747 & Model Q, Lost sales & Rp. 853.499.009 \\
Model Q, Lost sales & Rp. 855.081.747 & Model Q, Back order & Rp. 853.622.091 \\
\hline
\end{tabular}

Perbandingan dari seluruh metode yang digunakan, disajikan pada Tabel 7 dan Tabel 8. Model yang dapat memberikan ongkos persediaan yang paling optimum adalah jika perusahaan menggunakan sistem persediaan Model Q-Lost sales, berdasarkan hitungan usulan dalam penelitian ini. Selain dapat memberikan biaya minimum, model 
ini juga dapat memberikan tingkat pelayanan yang lebih tinggi dibandingkan model lainnya. yaitu sebesar 95\%,

\section{Simpulan}

Hasil penelitian menunjukan ongkos total persediaan tertinggi terdapat pada model $\mathrm{P}$ backorder sesuai kebijakan perusahaan, sedangkan dengan model yang sama dengan model $\mathrm{P}$ back order usulan menghasilkan biaya yang lebih kecil. Hal ini berlaku untuk seluruh model yang digunakan, di mana ketika dibandingkan model yang sama berdasarkan kebijakan perusahaan menghasilkan biaya persediaan lebih tinggi dibandingkan model usulan. Dapat disimpulkan dari ke-lima perhitungan yang digunakan dalam kebijakan persediaan optimal, model terbaik yang dapat digunakan adalah model Q - backorder. Hal ini mengindikasikan bahwa kebijakan yang dilakukan perusahaan dalam penentuan jumlah safety stock dinilai terlalu tinggi, yang berdampak pada bertambahnya biaya penyimpanan. Dengan menurunkan tingkat safety stock sesuai yang diusulkan, perusahaan dapat menekan biaya persediaan dengan tetap dapat memenuhi permintaan dengan tingkat pelayanan yang tinggi.

Penelitian ini terbatas pada pengendalian satu jenis produk, pengembangan selanjutnya dilakukan dengan mempertimbangkan persediaan multi-produk dengan lead time yang berbeda-beda. Hal ini dilakukan untuk menganalisis sistem secara lebih menyeluruh. Selain itu aplikasi peramalan dapat digunakan untuk menghitung biaya persediaan paling optimum untuk memperkirakan kondisi di masa yang akan datang.

\section{Daftar Notasi}

$\mathrm{Ob} \quad$ : Ongkos pembelian

Op : Ongkos pemesanan

f : Frekuensi pemesanan ()

A : Ongkos setiap kali pemesanan barang

Os : Ongkos simpan

$\mathrm{m}$ : Jumlah inventori rata-rata yang ada di gudang

Q : Jumlah barang untuk setiap kali pemesanan

$\mathrm{T} \quad$ : Waktu pemesanan dilakukan

Ss : Besarnya cadangan pengaman

$\mathrm{O}_{\mathrm{T}} \quad$ : ongkos inventori total

$\mathrm{N}$ : Ekspektasi permintaan yang tak terpenuhi

$\mathrm{D} \quad$ : demand (nilai rata-rata permintaan).

$\mathrm{S} \quad$ : standar deviasi nilai permintaan

$\mathrm{P} \quad$ : harga produk

L : lead time (waktu tunggu sampai barang sampai di gudang) selama 1 (satu) bulan.

A : biaya untuk tiap satu kali pemesanan.

h $\quad$ : biaya simpan per unit yang disesuaikan dengan ukuran pallet yang digunakan.

$\mathrm{Cu} \quad$ : biaya kekurangan produk, jika terjadi kekurangan barang di gudang.

$\mathrm{f}(\mathrm{za}) \quad$ : Fungsi dari nilai z distribusi normal standar untuk a

$\Psi(\mathrm{za}) \quad$ : Fungi dari nilai z distribusi normal standar untuk a selama lead time 


\section{Referensi}

[1] R. J. Tersine, Principles of inventory and materials management: Prentice Hall, 1994.

[2] Indrajit, E. Richardus, and R. Djokopranoto, Manajemen Persediaan: Barang Umum dan Suku Cadang untuk Keperluan Pemeliharaan." Perbaikan, dan Operasi. Jakarta: PT Gramedia Widiasarana Indonesia, 2003.

[3] W. J. Stevenson and M. Hojati, Operations Management. New York, NY: McGraw-Hill/Irwin., 2002.

[4] D. Marsetiya Utama, "Model Penentuan Lot Pemesanan Dengan Mempertimbangkan Unit Diskon dan Batasan Kapasitas Gudang dengan Program Dinamis," 2017, vol. 18, p. 9, 2017-08-24 2017.

[5] D. M. Utama, "Penentuan Lot Size Pemesanan Bahan Baku Dengan Batasan Kapasitas Gudang," Jurnal Ilmiah Teknik Industri, vol. 15, pp. 64-68, 2016.

[6] W. L. Winston and J. B. Goldberg, Operations research: applications and algorithms Belmont: Thomson/Brooks/Cole., 2004.

[7] W. S. Wijaya and I. G. A. Widyadana, "Penentuan Ukuran Pemesanan Material dengan Memperhatikan Decay Inventory dan Quantity Unit Discount," Jurnal Titra, vol. 1, pp. 57-62, 2013.

[8] E. Kusrini, "Sistem Persediaan Multi Item dengan Kendala Investasi dan Luas Gudang," Jurnal Teknoin, vol. 10, 2005.

[9] H. Prasetyo, M. T. Nugroho, and A. Pujiarti, "Pengembangan Model Persediaan Bahan Baku dengan Mempertimbangkan Waktu Kadaluwarsa dan Faktor Unit Diskon," Jurnal Ilmiah Teknik Industri, vol. 4, pp. 115-122, 2006.

[10] T. A. I. Puspita, E. Suryani, and R. Prasetianto, "Penerapan Economic Order Quantity (EOQ) Model dengan Faktor Diskon yang Diintegrasikan pada ADempiere untuk Optimasi Biaya Persediaan di KUD Dau Malang," Jurnal Teknik ITS, vol. 1, pp. A579-A584, 2012.

[11] S. Suryajaya, T. Octavia, and G. A. Widyadana, "Model Persediaan Bahan Baku Multi Item dengan Mempertimbangkan Masa Kadaluwarsa, Unit Diskon dan Permintaanyang Tidak Konstan," Jurnal Teknik Industri, vol. 14, pp. 97-105, 2012.

[12] E. Herjanto, Manajemen Persediaan. Jakarta: Grasindo, 2007.

[13] N. S. Dini, H. Haryono, and S. Suhartono, "Peramalan Kebutuhan Premium dengan Metode ARIMAX untuk Optimasi Persediaan di Wilayah TBBM Madiun.," Jurnal Sains dan Seni ITS, vol. 1, pp. D230-D235, 2010.

[14] S. N. Bahagia, Sistem Inventori. Bandung: Penerbit ITB, 2006.

[15] V. Lukitosari, "Penentuan Kuantitas Optimal Dan Reorder Point Pada Persediaan Suku Cadang Dengan Distribusi Gamma," Limits: Journal of Mathematics and Its Applications, vol. 9, pp. 33-39., 2012.

[16] A. A. Junia, "Perbandingan metode pengendalian persediaan bahan baku model probabilistik Q dan P dengan back order (studi kasus PT Pupuk Kujang Cikampek)," Institut Teknologi Harapan Bangsa, Bandung2015.

[17] R. J. Tersine, Principles of inventory and materials management. New York: Prentice Hall, 1994.

[18] F. D. Anggraini, M. A. Ilhami, and L. \& Herlina, " Penentuan persediaan bahan baku optimal menggunakan model Q dengan Lost sales pada industri air minum dalam kemasan," Jurnal Teknik Industri Untirta, vol. 1, 2013. 